\title{
The Correlation of Roasting Conditions in Selective Potassium Extraction from K-Feldspar Ore
}

\author{
Mete Tayhan Serdengeçti, Hüseyin Baştürkcü, Fırat Burat and Murat Olgaç Kangal * \\ Mineral Processing Engineering Department, Istanbul Technical University, Istanbul 34469, Turkey; \\ serdengecti@itu.edu.tr (M.T.S.); basturkcu@itu.edu.tr (H.B.); buratf@itu.edu.tr (F.B.) \\ * Correspondence: kangal@itu.edu.tr
}

Received: 17 January 2019; Accepted: 11 February 2019; Published: 13 February 2019

\begin{abstract}
Feldspar minerals are essential ingredients for the glass and ceramic-glass industries. The potassium element found in certain proportions in the composition of K-feldspar minerals has a fundamental function in the growth of plants. The production of potassium fertilizers is mostly made from the soluble minerals, which are located in lakes. Despite having a huge area of use in the agriculture industry, the reserves of these salts are limited and not evenly distributed in the earth's crust. Due to the high availability of feldspar reserves in the earth's crust, the production of potential potassium salts can provide a wide range of social and economic benefits. In this study, potassium extraction from a feldspar ore, which contained microcline, albite, muscovite, and quartz, was studied using chloridizing $\left(\mathrm{CaCl}_{2}\right)$ roasting followed by leaching. Direct leaching experiments were also performed on the sample by adapting various solvents. To emphasize the importance of roasting before the dissolution process, different parameters such as particle size, roasting temperature, and duration, as well as the feldspar $/ \mathrm{CaCl}_{2}$ ratio, were tested. Under the optimum conditions (i.e., -106 microns, $850 \mathrm{Co}, 60$ minutes, 1:1.5 feldspar: $\mathrm{CaCl}_{2}$ ), $99 \%$ of the potassium was successfully extracted from the ore feed.
\end{abstract}

Keywords: potassium extraction; feldspar; muscovite; chloridizing roasting

\section{Introduction}

Potassium is the seventh most abundant element in the world and it has a significant function in the growth of plants with nitrogen and phosphorus [1]. In agricultural areas, potassium is analyzed at certain intervals, and potassium addition is made according to analysis results. Worldwide, potash $\left(\mathrm{K}_{2} \mathrm{O}\right)$ fertilizers are produced from soluble reserves, and two main compounds are used as the potash source. The first one is potassium chloride $(\mathrm{KCl})$, and the known minerals of this compound are sylvite $(\mathrm{KCl})$ and carnallite $\left(\mathrm{KMgCl}_{3} \cdot 6\left(\mathrm{H}_{2} \mathrm{O}\right)\right)$. The second source is potassium sulphate $\left(\mathrm{K}_{2} \mathrm{SO}_{4}\right)$, and it is mostly found as kainite $\left(\mathrm{MgSO}_{4} \cdot \mathrm{KCl} \cdot 3\left(\mathrm{H}_{2} \mathrm{O}\right)\right)$ and leonite $\left(\mathrm{K}_{2} \mathrm{Mg}\left(\mathrm{SO}_{4}\right)_{2} \cdot 4\left(\mathrm{H}_{2} \mathrm{O}\right)\right)$. All of those minerals are mostly found in salt lake deposits. For some specific fruits and vegetables, potassium sulphate can only be used due to their sensitivity to chloride. However, potassium sulphate is not as commonly used as potassium chloride. Thus, potassium sulphate is mostly produced from potassium chloride by reacting it with sulphuric acid.

Feldspars, as a potential potassium resource, are the most common rock forming minerals and constitute about $60 \%$ of the earth's crust [2]. The general formula of feldspars is $X \mathrm{Al}_{(1-2)} \mathrm{Si}_{(3-2)} \mathrm{O}_{(8)}$, where $X$ can alter as $\mathrm{Na}, \mathrm{K}$, and $\mathrm{Ca}$. The feldspar group has nearly 20 recognized members but only two of them (sodium and potassium feldspars) are used commercially. When the $\mathrm{Na}_{2} \mathrm{O}$ content in feldspar is more than $7 \%$, it is classified as sodium feldspar, and it is named as potassium feldspar when the $\mathrm{K}_{2} \mathrm{O}$ content is above $10 \%$. These two feldspars are the most important inputs in the glass industry, and $70 \%$ of these feldspars are commercially used in this sector [3]. The impurities that 
affect the use of feldspars in industry are iron and titanium oxides, thus very important economic and technological benefits can be achieved by decreasing the contents of these impurities.

As a potential potash source, $\mathrm{K}$ bearing feldspars could be processed with a heat treatment followed by water leaching. This process might present an alternative potash production source and value-added products can be produced from the feldspars. Despite having deep background information, there is still no plant that produces potash from feldspars. Most of the studies carried out on this subject did not conduct an economic evaluation. However, this situation can be re-evaluated using today's technologies. Similar studies related to this topic are explained below.

In the last century, the studies on the production of potash from feldspar mainly involved roasting and then water dissolution. Nayak et al. reported that $65 \%$ of the potassium could be dissolved from $13 \% \mathrm{~K}_{2} \mathrm{O}$ bearing rock with roasting at $850-900{ }^{\circ} \mathrm{C}$ together with $\mathrm{MgSO}_{4}+\mathrm{CaCO}_{3}$ at a ratio of 1:0.7:3 to feldspar, with the feldspar having a grain size under 63 microns [4]. Zhang et al. [5] claimed that when feldspar: $\mathrm{CaCl}_{2}: \mathrm{NaCl}$ roasted together at a ratio of 1.8:1.1:0.6 at $800{ }^{\circ} \mathrm{C}$ for 1 hour, the potassium extraction reached $95.5 \%$, starting from $14.81 \% \mathrm{~K}_{2} \mathrm{O}$ bearing feldspar with a grain size under 70 microns. Xie et al. [6] stated that $84.7 \%$ potassium recovery was obtained from $9.3 \% \mathrm{~K}_{2} \mathrm{O}$ bearing feldspar, minus 45 microns feldspar ore with $\mathrm{CaCl}_{2}$, by roasting at $800{ }^{\circ} \mathrm{C}$ for 1 hour. Jena et al. [7] showed that $99.6 \%$ potassium from $5.4 \%$ potassium bearing nepheline syenite was extracted with the addition of $\mathrm{CaCl}_{2}\left(45 \%\right.$ weight to the feed) at a roasting temperature of $900{ }^{\circ} \mathrm{C}$ and 15 minutes mechanical activation. Pradhan et al. investigated the effect of $\mathrm{NaCl}, \mathrm{CaCl}_{2}, \mathrm{Na}_{2} \mathrm{CO}_{3}, \mathrm{BaCl}_{2}$, and $\mathrm{Ca}(\mathrm{OH})_{2}$ on potassium extraction from feldspar ore that was ground to a grain size below 74 microns. The roasting temperature and duration were selected as $900{ }^{\circ} \mathrm{C}$ and 1 hour, respectively. They achieved $36 \%$ and $28 \%$ potassium recovery from $9.8 \% \mathrm{~K}_{2} \mathrm{O}$ bearing feldspar using $\mathrm{CaCl}_{2}$ and $\mathrm{NaCl}$ [8]. Yuan et al. reported that $91 \%$ potassium recovery could be achieved from $13.3 \% \mathrm{~K}_{2} \mathrm{O}$ bearing feldspar under 50 microns particle size when the roasting temperature was adjusted to $900{ }^{\circ} \mathrm{C}$, and roasting took place for 40 minutes in a dry nitrogen atmosphere with the addition of $1: 1.5 \mathrm{CaCl}_{2}$ to the feldspar [9]. Orosco and Ruiz indicated that $93 \%$ potassium recovery from $10.43 \%$ potassium bearing feldspar could be achieved with the addition of $1: 1 \mathrm{MgCl}_{2}$ to the feldspar and roasting at $900{ }^{\circ} \mathrm{C}$ [10]. Kumanan et al. announced $90 \%$ potassium recovery from $8 \% \mathrm{~K}_{2} \mathrm{O}$ bearing feldspar below 70 microns with the addition of 1:8 $\mathrm{CaCl}_{2}$ to potassium feldspar at a roasting temperature of $900{ }^{\circ} \mathrm{C}$, for an 8-hour duration [11]. Jena et al. reached $92.8 \%$ potassium recovery from $10.89 \% \mathrm{~K}_{2} \mathrm{O}$ bearing feldspar with the addition of the same amount of $\mathrm{NaCl}$ and phosphogypsum at a roasting temperature of $900{ }^{\circ} \mathrm{C}$, for a 1-hour duration [12]. Jena et al. also showed that $85 \%$ of potassium could be dissolved from $5.4 \% \mathrm{~K}_{2} \mathrm{O}$ bearing nepheline syenite ground below 150 microns with the addition of $20 \%$ charcoal and $30 \% \mathrm{CaCl}_{2}$ by weight, using microwave roasting at $900 \mathrm{~W}$ for 8 minutes at $727^{\circ} \mathrm{C}$ [13].

In this study, potassium extraction from feldspar ore was studied using chloridizing $\left(\mathrm{CaCl}_{2}\right)$ roasting followed by leaching, and the variable parameters such as solvent type and particle size were investigated by extensively adapting the calcination temperature-duration correlation for the first time. In this study, systematic analyses using calcium chloride for the production of potassium salts from potassium feldspar ore containing high muscovite were performed using potassium chloride at much lower temperatures, shorter times, and with a lesser amount of calcium chloride.

\section{Experimental Studies}

\subsection{Material and Characterization}

The potassium feldspar sample obtained from the Buzlukdagi Region, Kırşehir, Turkey was used in the experimental studies. The chemical content of the sample was determined using the inductively coupled plasma (ICP) method, and the results are given in Table 1. X-ray diffraction analysis was conducted using a $\mathrm{Cu}$ X-ray sourced Panalytical X'Pert Pro diffractometer. Figure 1 shows the XRD analysis results. According to the results, the dominant minerals were K-Feldspar, albite, muscovite, albite, and quartz. 
Table 1. Chemical analysis results of the sample.

\begin{tabular}{cccc}
\hline Element & Content, $\%$ & Element & Content, $\%$ \\
\hline $\mathrm{Si}$ & 28.50 & $\mathrm{Ca}$ & 0.22 \\
$\mathrm{Al}$ & 12.26 & $\mathrm{Mg}$ & 0.11 \\
$\mathrm{~K}$ & 7.98 & $\mathrm{Ti}$ & 0.06 \\
$\mathrm{Na}$ & 2.83 & $\mathrm{P}$ & 0.3 \\
$\mathrm{Fe}$ & 0.85 & & \\
\hline
\end{tabular}

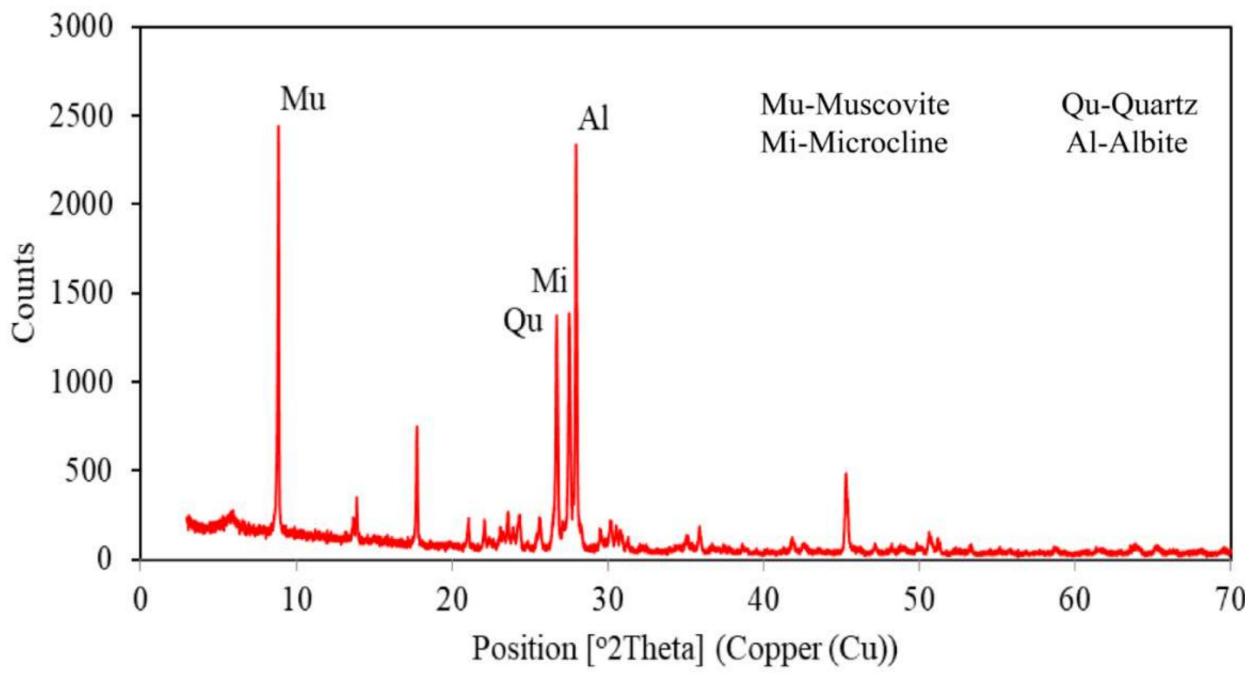

Figure 1. X-Ray Diffraction (XRD) patterns of the sample.

Scanning electron microscope (SEM-BSE) analysis using the Bruker 5010 SDD (Billerica, MA, USA) device showed the presence of K-feldspar in the ore (Figure 2).
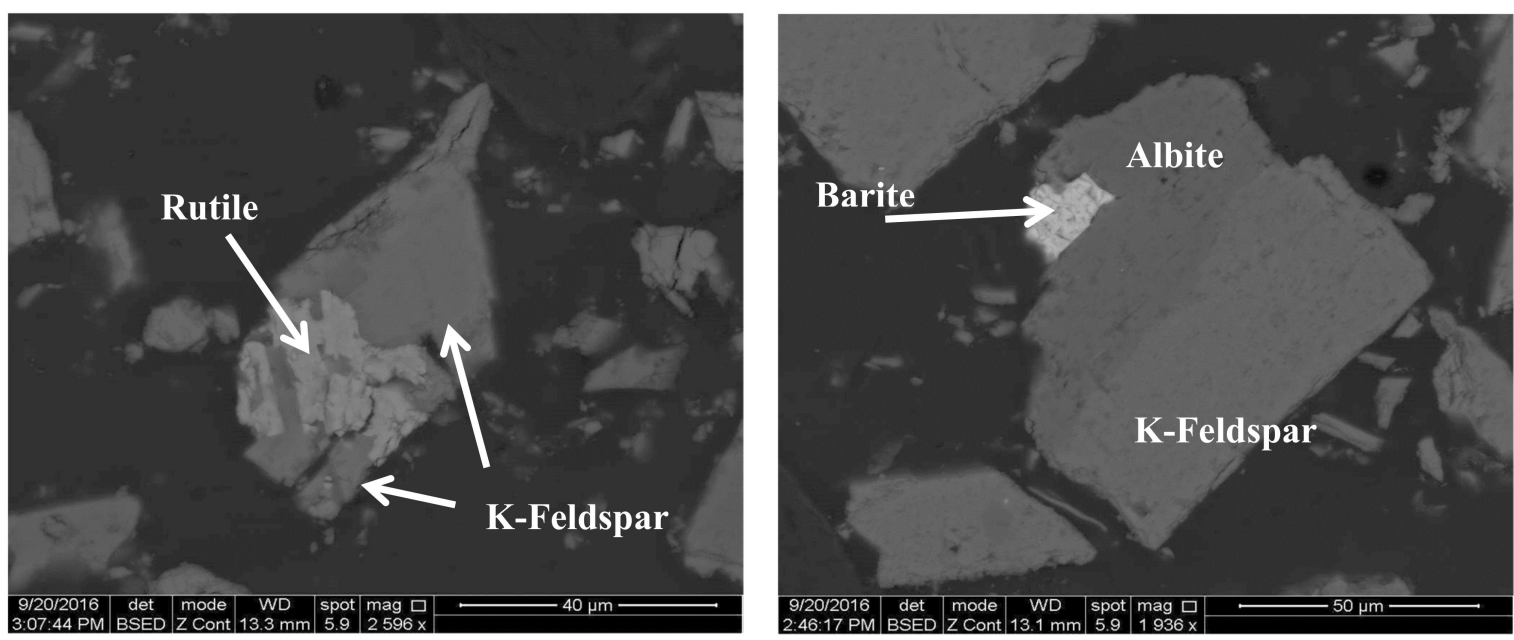

Figure 2. Backscattered electrons (BSE) images of the sample.

Mineral liberalization analysis was performed with a FEI MLA 650F (Hillsboro, OR, USA). According to liberation analysis shown in Figure 3, K-feldspar is liberated below $200 \mu \mathrm{m}$ with liberation degree of about $75 \%$. 


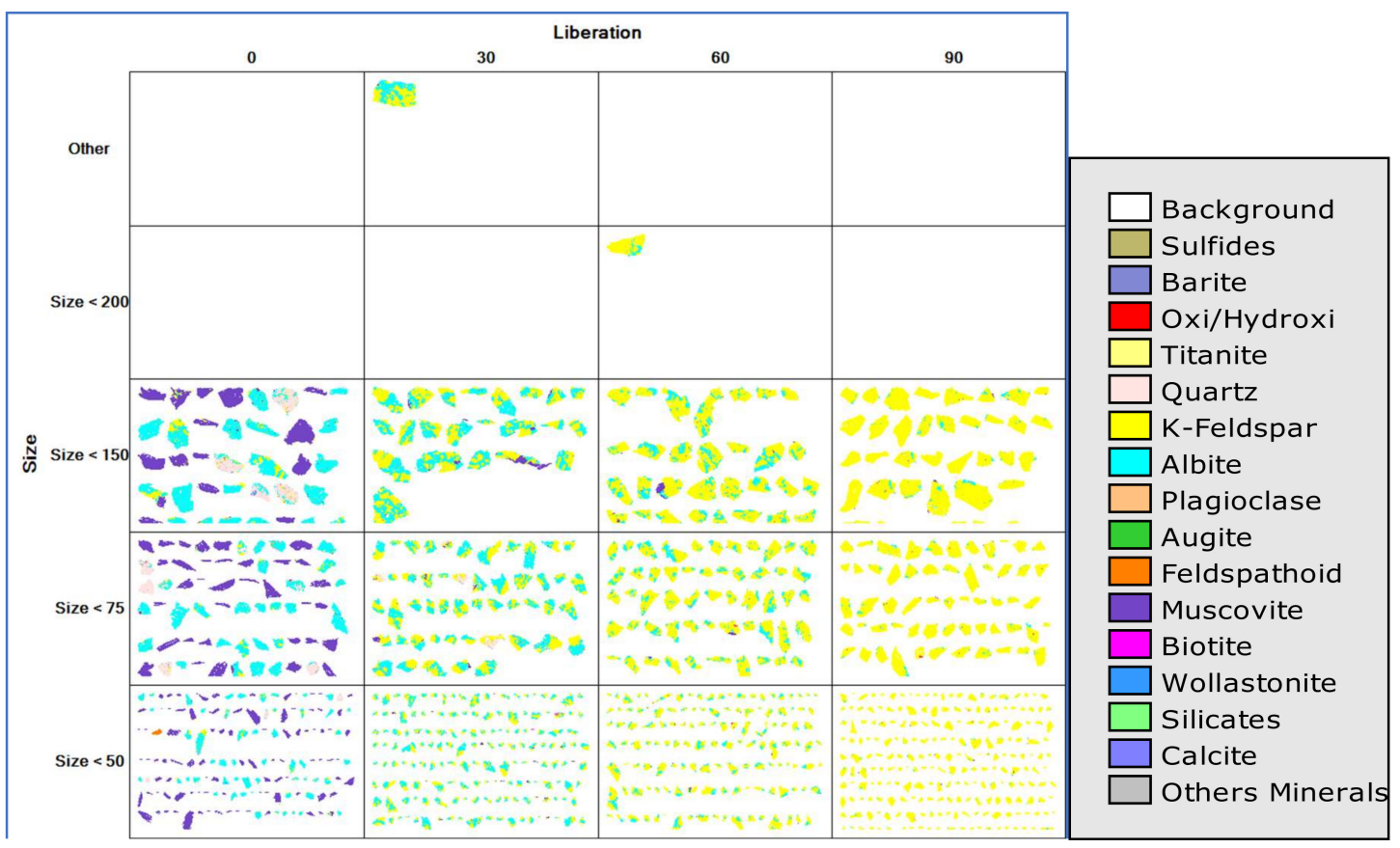

Figure 3. Image analysis of the sample.

\subsection{Beneficiation Methods}

The laboratory type ceramic mill with alumina balls was used for grinding the representative ore sample from $2 \mathrm{~mm}$ to below $212 \mu \mathrm{m}, 106 \mu \mathrm{m}$, and $74 \mu \mathrm{m}$. In direct leaching experiments, 20\% purity hydrochloric acid and 95\% purity sulphuric acid from VWR Chemicals were used. Pure granular anhydrous calcium chloride obtained from Carlo Erba Reagents was ground in an agate mortar and mixed uniformly to different size groups of K-feldspar samples based on a certain ratio. Thereafter, $7.5 \mathrm{~g}$ of mixture was added to each porcelain crucible and the roasting tests were performed in a muffle furnace at elevated temperatures using $30 \mathrm{~g}$ of mixture. After weighing the roasted samples, $15 \mathrm{~g}$ were separated and used in a dissolution process. Leaching experiments were carried out on pulp with a $10 \%$ solid ratio at $60{ }^{\circ} \mathrm{C}$ temperature for 2 hours. The pulp was mixed using a magnetic stirrer at $500 \mathrm{rpm}$. Liquid/solid separation was performed using a lab scale vacuum filter with blue ribbon filter papers. The filtered cake was dried at $70{ }^{\circ} \mathrm{C}$ for around 24 hours. Ion contents of the pregnant solutions was analyzed by the atomic adsorption spectrometry (AAS) method using the Varian AA240FS device (Palo Alto, CA, USA). Figure 4 presents the flowsheet of the experimental study. 


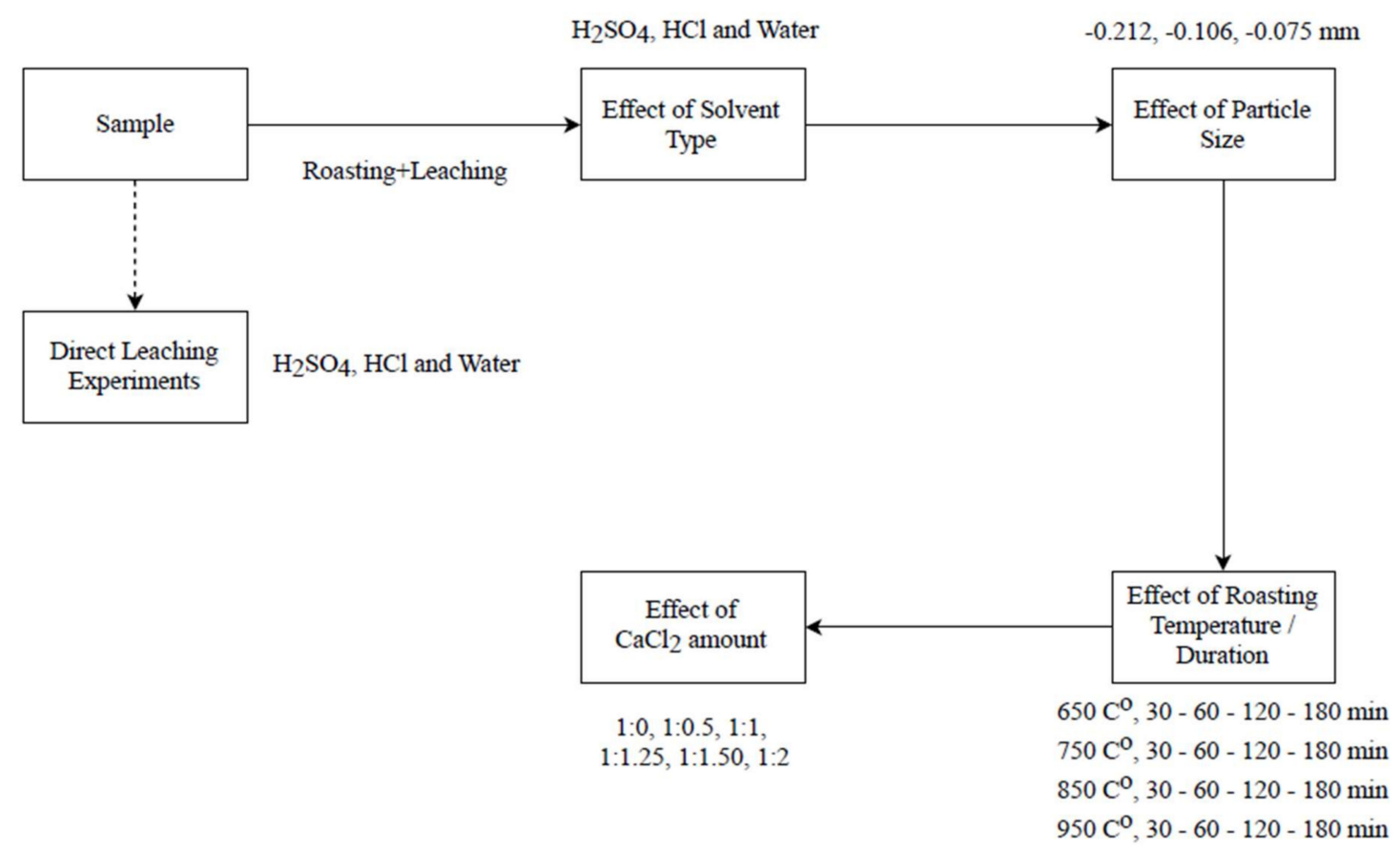

Figure 4. General flowsheet of the experimental studies.

\section{Results}

\subsection{Direct Leaching Experiments}

The possibilities of extracting potassium in the feldspar's composition were investigated by direct leaching and roasting, followed by the leaching process. The results from two different methods were compared according to the obtained dissolution data. Alumina content was monitored to understand the dissolution mechanism, that is, whether it occurred random or selectively. We chose an $8 \mathrm{M}$ acid concentration and $90{ }^{\circ} \mathrm{C}$ leaching temperature. Although very high amounts of acid were used, the dissolution recoveries remained at very low levels after 2 hours of leaching (Table 2). The increase in dissolution time might have been increased and the dissolution recovery values could have been enhanced to some extent, but it was very difficult to achieve the desired high recovery rates without the roasting process. Similar to our findings, Kumanan et al. reached only $16 \%$ potassium extraction at a $90{ }^{\circ} \mathrm{C}$ temperature and $10 \mathrm{M} \mathrm{H}_{2} \mathrm{SO}_{4}$ concentration [11].

Table 2. $\mathrm{K}$ and $\mathrm{Al}$ recoveries after direct leaching experiments.

\begin{tabular}{ccc}
\hline \multirow{2}{*}{ Solvent Type } & \multicolumn{3}{c}{ Extraction, \% } \\
\cline { 2 - 3 } & $\mathbf{K}$ & $\mathbf{A 1}$ \\
\hline $8 \mathrm{M} \mathrm{HCl}$ & 1.4 & 9.4 \\
$8 \mathrm{M} \mathrm{H}_{2} \mathrm{SO}_{4}$ & 1.1 & 8.9 \\
Water & 0.0 & 0.2 \\
\hline
\end{tabular}

\subsection{The Roasting Followed by Leaching}

The result showed that in the direct dissolution experiments, even applying very high concentrations of acids, the ore did not respond to direct leaching. Therefore, the necessity of roasting emerged. In the roasting experiments, the effect of solvent type, particle size, roasting temperature/duration, and the amount of $\mathrm{CaCl}_{2}$ were investigated. 


\subsubsection{Effect of Solvent Type}

$\mathrm{HCl}, \mathrm{H}_{2} \mathrm{SO}_{4}$, and water were used as solvents to investigate the effect of various types of solvents on the potassium extraction of roasted products. The roasting temperature and duration were chosen as $750{ }^{\circ} \mathrm{C}$ and 120 minutes, respectively. The particle size of the feed was below $106 \mu \mathrm{m}$, and the feldspar: $\mathrm{CaCl}_{2}$ ratio was adjusted to 1:1.5. Given the emerging problem of gelation from using vacuum filtration, the centrifugation method was used in the dewatering process. The results are given in Table 3.

Table 3. The effect of solvent type on $\mathrm{K}$ and $\mathrm{Al}$ dissolution after the roasting process.

\begin{tabular}{ccc}
\hline \multirow{2}{*}{ Solvent Type } & \multicolumn{2}{c}{ Extraction, \% } \\
\cline { 2 - 3 } & $\mathbf{K}$ & $\mathbf{A l}$ \\
\hline $2 \mathrm{M} \mathrm{H}_{2} \mathrm{SO}_{4}$ & 24.1 & 44.0 \\
$2 \mathrm{M} \mathrm{HCl}$ & 76.4 & 67.5 \\
Water & 52.6 & 0.0 \\
\hline
\end{tabular}

Table 3 clearly shows that $\mathrm{HCl}$ provides the highest potassium extraction rate by $76.4 \%$, while water only dissolves $52.6 \%$ of the potassium because of the formation of $\mathrm{KCl}$ during roasting, based on the below equations:

$$
\begin{gathered}
\mathrm{KAlSi}_{3} \mathrm{O}_{8}+4 \mathrm{HCl}+4 \mathrm{H}_{2} \mathrm{O}=\mathrm{AlCl}_{3}+3 \mathrm{H}_{4} \mathrm{SiO}_{4}+\mathrm{KCl} \\
4 \mathrm{KAlSi}_{3} \mathrm{O}_{8}+22 \mathrm{H}_{2} \mathrm{O}=\mathrm{Al}_{4} \mathrm{Si}_{4} \mathrm{O}_{10}(\mathrm{OH})_{8}+8 \mathrm{H}_{4} \mathrm{SiO}_{4}+4 \mathrm{KOH}
\end{gathered}
$$

Water was used as the solvent in the subsequent experiments, since potassium was only selectively obtained in the solution made with water.

\subsubsection{Effect of Particle Size}

The effect of particle size on potassium extraction was investigated using three different fractions $(-212,-106$, and $-75 \mu \mathrm{m})$. The roasting tests were managed at the optimized values of $750{ }^{\circ} \mathrm{C}$ temperature and for 120 minutes roasting time. $\mathrm{CaCl}_{2}$ addition was kept similar to the previous experiment. Water was used as the solvent. The results in Table 4 show that the particle size had no significant effect on potassium dissolution.

Table 4. Effect of particle size on potassium recovery.

\begin{tabular}{ccc}
\hline \multirow{2}{*}{ Feed Size, $\boldsymbol{\mu m}$} & \multicolumn{3}{c}{ Extraction, \% } \\
\cline { 2 - 3 } & $\mathbf{K}$ & $\mathbf{A l}$ \\
\hline 75 & 53.4 & 0.1 \\
106 & 52.1 & 0.1 \\
212 & 52.8 & 0.2 \\
\hline
\end{tabular}

Similar to our findings, Jena et al. [13] stated that only a $10 \%$ increase in potassium dissolution efficiency was achieved when the feeding size was reduced from 210 microns to 75 microns, at a roasting temperature of $900{ }^{\circ} \mathrm{C}$ and duration of 60 minutes. The reason for the increase obtained at 75 microns was that the sample had been sufficiently decomposed by the roasting process. With the implementation of this method, the roasting costs will increase to some extent, but shorter milling operations will significantly reduce the milling costs. According to the results given in Table $4,-212 \mu \mathrm{m}$ was considered to be the most suitable particle size. However, it was observed that increasing the particle size caused adhesion between the particles. Some amount of adhesion was detected in the grains below $106 \mu \mathrm{m}$ (Figure 5), but it was removed from the container in which it was attached without much effort. Therefore, $\mathrm{a}-106 \mu \mathrm{m}$ fraction was selected as the optimum for the following tests. 


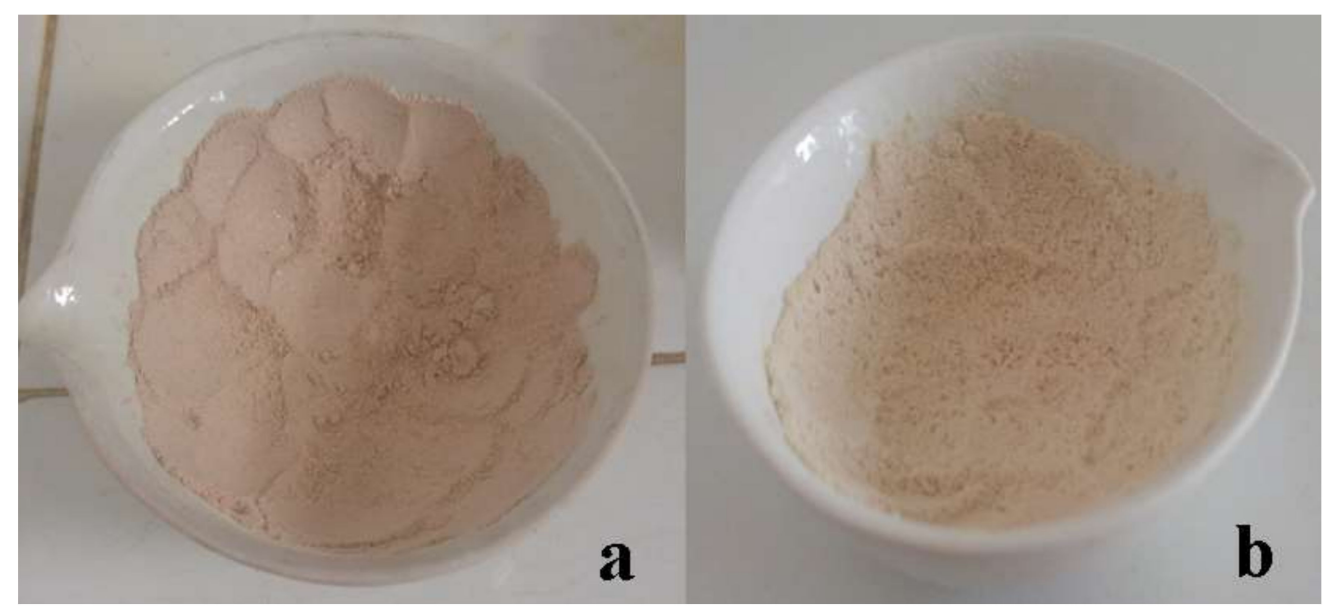

Figure 5. (a) $\mathrm{CaCl}_{2}+\mathrm{K}$-Feldspar mixture before roasting. (b) $\mathrm{CaCl}_{2}+\mathrm{K}$-Feldspar mixture after roasting.

\subsubsection{Effect of Roasting Temperature and Duration}

Roasting is the most critical step of potassium extraction from potassium feldspar. Two main parameters, that is, temperature and roasting duration, impact the success of the process. In this experiment, first, the feldspar: $\mathrm{CaCl}_{2}$ ratio was kept constant at 1:1.5, and then, the leaching tests were performed at a $10 \%$ solid in pulp ratio, $60^{\circ} \mathrm{C}$ pulp temperature, and a 2 hour leaching time. Figure 6 shows the results of the dissolution experiments in which the sample was roasted at temperatures of $650,750,850$, and $950^{\circ} \mathrm{C}$ and for $30,60,120$, and 180 minutes.

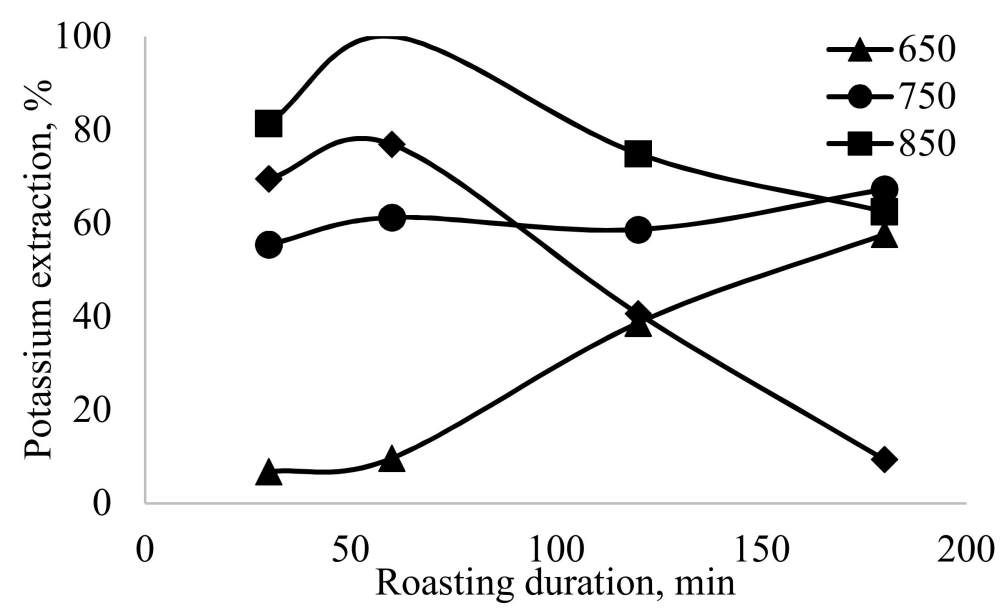

Figure 6. Potassium extraction recoveries of the roasted sample at different temperature values and durations.

Researchers who conducted similar potassium extraction studies stated that the highest recoveries were obtained at $800{ }^{\circ} \mathrm{C}[5,6]$ and $900{ }^{\circ} \mathrm{C}[4,7,8,10,11,13]$. Yuan et al. [9] observed a decrease in the potassium yields at elevated temperatures, similar to the findings of this study. Figure 6 shows that the highest potassium extraction was obtained at an $850{ }^{\circ} \mathrm{C}$ roasting temperature and at a 60 minutes roasting time.

Despite the melting point of $\mathrm{CaCl}_{2}$ being $772{ }^{\circ} \mathrm{C}$, the activation of $\mathrm{KCl}$ starts at around $650{ }^{\circ} \mathrm{C}$ after 60 minutes. The dissolution curve of the roasted sample at $750{ }^{\circ} \mathrm{C}$ did not change much and had an almost linear line for all durations (Figure 6). The extraction value of the roasted sample at $950{ }^{\circ} \mathrm{C}$ was lower than the roasted sample at $850^{\circ} \mathrm{C}$ for all the duration values. This recovery reduction between 850 and $950^{\circ} \mathrm{C}$ could be explained by mass losses during the roasting process (Figure 7). 


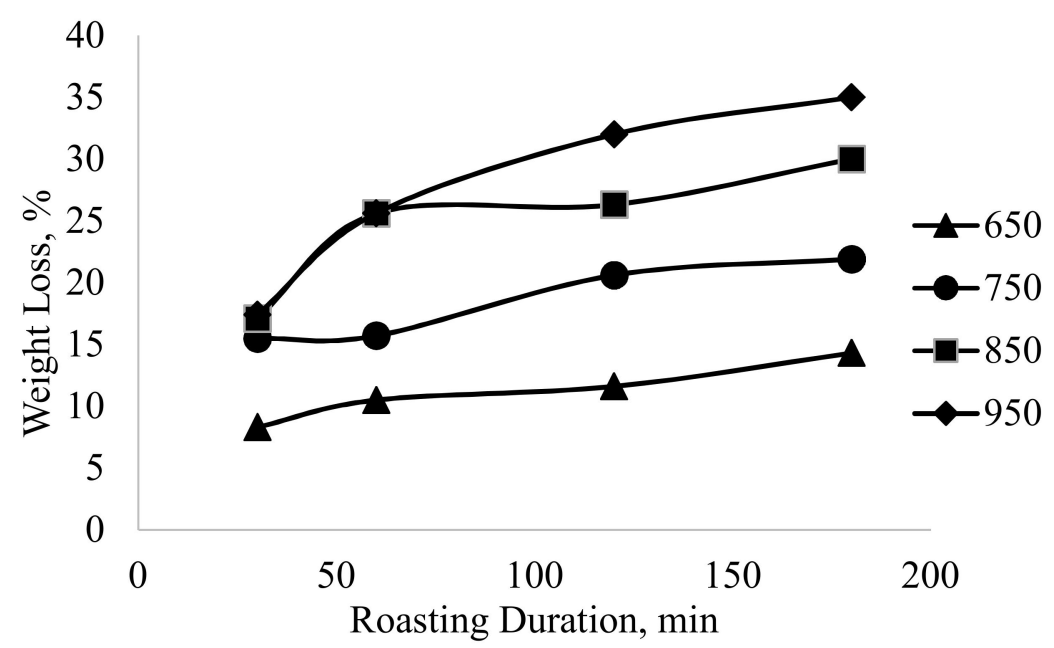

Figure 7. Mass losses at the roasting.

As seen in Figure 7, it is observed that the mass losses increase as the temperature increases. It is also known that the boiling point of pure sodium and potassium elements is $882^{\circ} \mathrm{C}$ and $759{ }^{\circ} \mathrm{C}$, respectively. It can be said that the decrease in potassium extraction rates for long periods and temperatures depends on the evaporation of alkalis. It would not be correct to associate mass loss directly with recovery because of the humidity. As mentioned in the materials section, the experiments were conducted using anhydrous granular $\mathrm{CaCl}_{2}$, and it was ground in an agate mortar before mixing. When it is being ground, $\mathrm{CaCl}_{2}$ captures humidity from the air. Even after keeping it for 30 seconds under room conditions, there were observable water drops occurring around it. Thus, some of this mass loss was related to humidity. Therefore, XRD analysis was performed on the leach cakes of each roasting temperature at a 60-minute duration scale.

\subsubsection{Effect of the $\mathrm{CaCl}_{2}$ Amount}

The effect of the feldspar: $\mathrm{CaCl}_{2}$ ratio was investigated under the optimized roasting temperature and duration $\left(850^{\circ} \mathrm{C}\right.$ and 60 minutes). Our previous findings showed that potassium in feldspar can be completely dissolved at a 1:1.5 feldspar: $\mathrm{CaCl}_{2}$ ratio. As suggested by Yuan et al. [9] the following equation can explain the possible transition:

$$
\mathrm{CaCl}_{2}(\mathrm{~s}, \mathrm{l})+2 \mathrm{KAlSi}_{3} \mathrm{O}_{8}(\mathrm{~s})=\mathrm{CaAl}_{2} \mathrm{Si}_{2} \mathrm{O}_{8}+4 \mathrm{SiO}_{2}(\mathrm{~s})+2 \mathrm{KCl}(\mathrm{s}, \mathrm{l})
$$

Equation (3) expresses that $\mathrm{CaCl}_{2}$ salt replaces with $\mathrm{K}$ of the microcline and forms calcium aluminum silicate, which is another feldspar (anorthite). The reaction shows that the $\mathrm{CaCl}_{2}$ amount must be high enough to activate all of the potassium in the microcline structure for the highest recovery. Therefore, the effect of the $\mathrm{CaCl}_{2}$ amount was investigated at different feldspar: $\mathrm{CaCl}_{2}$ ratios $(1: 0,1: 0.5$, $1: 1,1: 1.25,1: 1.5$, and 1:2). Figure 8 illustrates that there is a sharp increase after the 1:1 ratio and the highest extraction was achieved at a $1: 1.5 \mathrm{CaCl}_{2}$ ratio. 


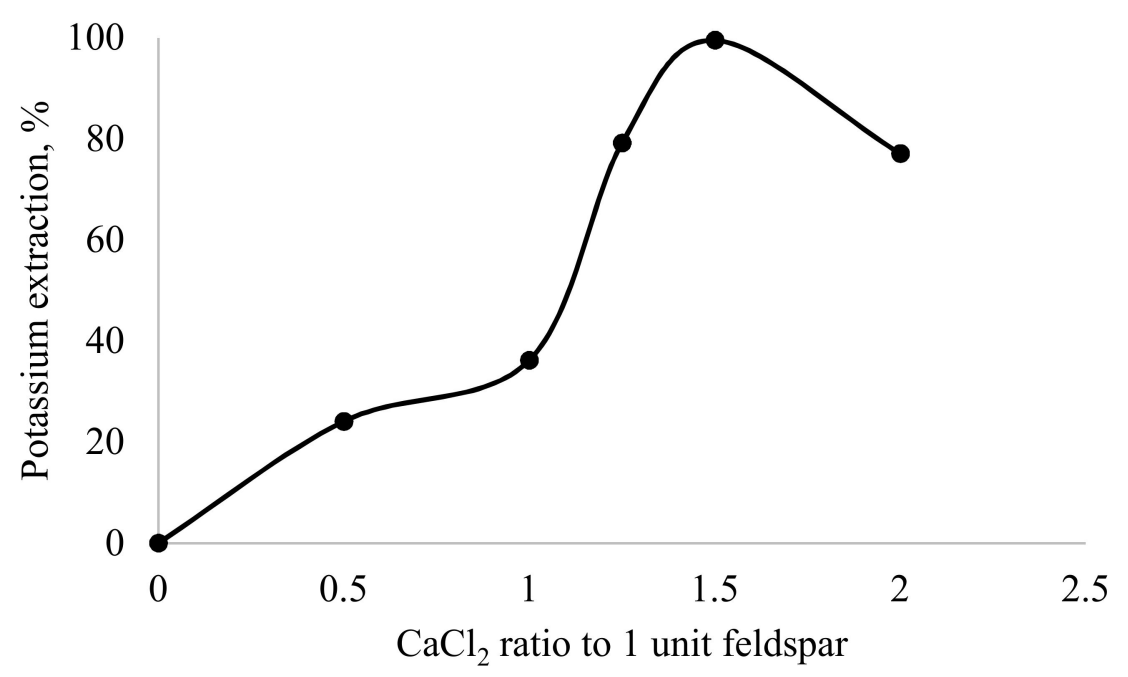

Figure 8. Effect of the $\mathrm{CaCl}_{2}$ amount.

Jena et al. [12] prepared a feed with a 1:0.8 $\mathrm{CaCl}_{2}$ :nepheline syenite ratio for the mechanical activation process, and they reached a $99.6 \%$ potassium extraction. Yuan et al. [9] achieved a 91.8\% potassium extraction value after combining $\mathrm{CaCl}_{2}$ with feldspar at a ratio of 1:1.5. Although the transformation of microcline is shown in Equation (3), the ore in this study also contained albite and muscovite. The formula of muscovite $\left(\mathrm{KAl}_{2} \mathrm{Si}_{3} \mathrm{AlO}_{10}(\mathrm{OH})_{2}\right)$ is somewhat similar to microcline $\left(\mathrm{KAlSi}_{3} \mathrm{O}_{9}\right)$; however, the decomposition temperatures between them are different. In addition, as understood from the sodium extraction values, a part of the calcium in $\mathrm{CaCl}_{2}$ consumes albite and $\mathrm{NaCl}$ salt is formed. To see these transformations, XRD analysis was also applied to the roasted product and the leaching cake. The XRD analysis results in Figure 9 show the formations of bulk, roasted and leach residue comparatively.

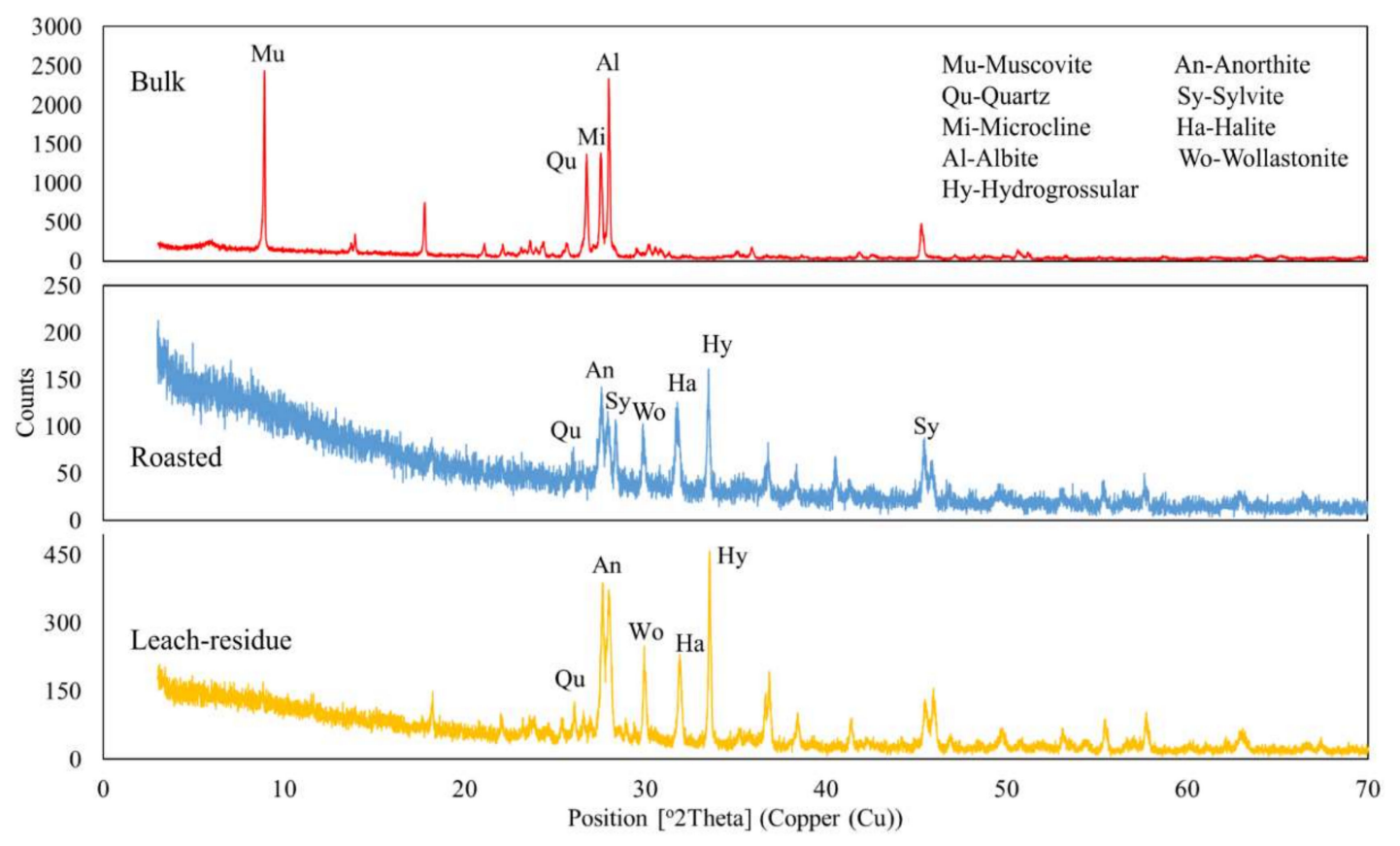

Figure 9. XRD patterns of bulk, roasted and leach residue.

Figure 9 reveals that after the roasting process, anorthite, halite, sylvite, wollastonite, and hydrogrossular were formed from the raw ore. The transformation of the minerals was thought to be as follows: (i) microcline was converted to sylvite and anorthite, (ii) albite was converted to halite 
and anorthite, (iii) silica $\left(\mathrm{SiO}_{2}\right)$ was converted to wollastonite, and (iv) muscovite was converted to hydrogrossular, which is a mineral series in the garnet group. The transition of microcline to anorthite and quartz was found in the literature. For example, Jena et al. [14] used pyrophillite mine waste containing 52\% muscovite, 30\% pyrophyllite, and 13\% microcline. They observed almandine formation after roasting with $\mathrm{CaCl}_{2}$, which is a member of the garnet group, and the chemical formula was $\mathrm{Fe}^{2+} 3 \mathrm{Al}_{2}\left(\mathrm{SiO}_{4}\right)_{3}$. Moreover, $75 \%$ by weight $\mathrm{CaCl}_{2}$ was added to the fed ore and a potassium dissolution efficiency of over $80 \%$ was obtained [14]. According to these results, it was understood that microcline consumed too much $\mathrm{CaCl}_{2}$ and converted to a garnet group mineral series, hydrogrossular, with the chemical formula of $\mathrm{Ca}_{3} \mathrm{Al}_{2}\left(\mathrm{SiO}_{4}\right)_{3-\mathrm{x}}(\mathrm{OH})_{4 x}$, with $(\mathrm{OH})$ partly replacing $\left(\mathrm{SiO}_{4}\right)$, where the value of $\mathrm{x}$ determines whether it is grossular, hibschite, or katoite. From an economic point of view, the increase in muscovite content promotes the consumption of $\mathrm{CaCl}_{2}$ and almost $100 \%$ potassium extraction was achieved. Therefore, patterns in both the roasted product and leach residue showed that a high portion of halite remained in the leach residue as a result of the solid/liquid separation or leaching conditions.

\section{Conclusions}

Potassium, which is a key component in the agriculture and ceramic-glass industries, is expected to be produced at a global volume of nearly 43 million tons in 2019 [15]. Therefore, the production of high value added products from potential potassium resources has received increased attention. In the scope of this study, K-feldspar was used as an alternative source and a series of experiments were performed to extract potassium in an efficient way.

Feldspar ore mainly consists of microcline, albite, and muscovite with a $9.69 \% \mathrm{~K}_{2} \mathrm{O}$ total content. The potential of potassium production from this ore, as a source of potash for the agricultural industry, was investigated using roasting followed by a leaching process. The experimental studies showed that leaching without roasting did not result in potassium extraction from feldspar. Thus, roasting followed by a leaching method was applied. Since water is economic and selective for salty compounds, it was chosen as the solvent. The optimum particle size was found to be $-106 \mu \mathrm{m}$ because $-212 \mu \mathrm{m}$ showed powerful adhesion. The roasting time was investigated in detail and the highest potassium extraction was obtained at $850{ }^{\circ} \mathrm{C}$ for 60 minutes. The optimum feldspar: $\mathrm{CaCl}_{2}$ ratio was found to be $1: 1.5$, and $99.8 \%$ of the potassium was successfully extracted from the representative potassium feldspar ore.

Although roasting feldspar with $\mathrm{CaCl}_{2}$ has been investigated in many studies, this study's approach was novel in terms of expressing the correlation between roasting duration and temperature. A more particular achievement of this study was that potassium extraction of a feldspar ore with a high impurity content was achieved.

On the other hand, it should be noted that the roasting process is an energy intensive process. The occurrence of the substitution reaction between feldspar and additives such as $\mathrm{CaCl}_{2}$ requires relatively high temperatures. As the mechanism of this reaction was revealed properly, alternative methods to initiate the reaction should be investigated in further studies. In this concept; low roasting temperature, fewer and more cost-effective additives, and/or various techniques to apply external force on the sample could be the essential topics.

Author Contributions: M.O.K. and M.T.S. conceived and designed the experiments; all researchers performed the experiments and analyzed the data; M.O.K., M.T.S. and F.B. wrote the paper.

Funding: This research was funded by The Scientific and Technological Research Council of Turkey (TUBITAK), Project No: 218M107.

Acknowledgments: The authors would like to express their sincere thanks and appreciation to The Scientific and Technological Research Council of Turkey (Project No: 218M107) for the financial support, and to BS Invest Co. for kindly providing the feldspar samples.

Conflicts of Interest: The authors declare no conflict of interest. 


\section{References}

1. Scherer, H.W.; Mengel, K.; Dittmar, H.; Drach, M.; Vosskamp, R.; Trenkel, M.E.; Gutser, R.; Steffens, G.; Czikkely, V.; Niedermaier, T.; et al. Fertilizers. In Ullmann's Encyclopedia of Industrial Chemistry; Wiley-VCH Verlag GmbH \& Co. KGaA: Weinheim, Germany, 2002.

2. Rao, J.R.; Nayak, R.; Suryanarayana, A. Feldspar for potassium, fertilizers, catalysts and cement. Asian J. Chem. 1998, 10, 690-706.

3. Ahmed, M.M.; Ibrahim, G.A.; Rizk, A.M.E.; Mahmoud, N.A. Reduce the iron content in Egyptian feldspar ore of Wadi Zirib for industrial applications. Int. J. Min. Eng. Miner. Process. 2016, 5, 25-34.

4. Nayak, R.; Rao, J.R.; Suryanarayana, A.; Nayak, B.B. A Process for Extraction of Potassium from Feldspar. Indian Patent No. 217121, 31 March 2008.

5. Zhang, H.; Sun, D.S.; Bao, H. The extraction of potassium from feldspar by molten salt leaching method with composite additives. Adv. Mater. Res. 2012, 524, 1136-1139. [CrossRef]

6. Xie, H.; Wang, Y.; Ju, Y.; Liang, B.; Zhu, J.; Zhang, R.; Xie, L.; Liu, T.; Zhou, X.; Zeng, H.; et al. Simultaneous mineralization of $\mathrm{CO}_{2}$ and recovery of soluble potassium using earth-abundant potassium feldspar. Chin. Sci. Bull. 2013, 58, 128-132. [CrossRef]

7. Jena, S.K.; Dhawan, N.; Rao, D.S.; Misra, P.K.; Mishra, B.K.; Das, B. Studies on extraction of potassium values from nepheline syenite. Int. J. Miner. Process. 2014, 133, 13-22. [CrossRef]

8. Pradhan, G.K.; Singh, Y.P.; Dhawan, N. Silicate Rocks-A potash source for fertilizers. In Proceedings of the India International Science Festival-Young Scientists' Meet, Delhi, India, 4-8 December 2015; pp. 1-9.

9. Yuan, B.; Li, C.; Liang, B.; Lü, L.; Yue, H.; Sheng, H.; Ye, L.; Xie, H. Extraction of potassium from K-feldspar via the $\mathrm{CaCl}_{2}$ calcination route. Chin. J. Chem. Eng. 2015, 23, 1557-1564. [CrossRef]

10. Orosco, P.; del Carmen Ruiz, M. Potassium chloride production by microcline chlorination. Thermochim. Acta 2015, 613, 108-112. [CrossRef]

11. Kumanan, M.; Sathya, G.; Nandakumar, V.; Berchmans, L.J. Extraction of potash from K-Feldspar mineral by acid and molten salt leaching processes. IASET Int. J. Metall. Mater. Chem. Eng. 2016, 7, 1-10.

12. Jena, S.K.; Misra, P.K.; Das, B. Studies on extraction of potassium from feldspar by roast-leach method using phosphogypsum and sodium chloride. Min. Process. Extr. Metall. 2016, 37, 323-332. [CrossRef]

13. Jena, S.K.; Dhawan, N.; Rath, S.S.; Rao, D.S.; Das, B. Investigation of microwave roasting for potash extraction from nepheline syenite. Sep. Purif. Technol. 2016, 161, 104-111. [CrossRef]

14. Jena, S.K.; Dhawan, N.; Rao, D.S.; Misra, P.K.; Das, B. Extraction of potash values from pyrophyllite mine waste. Sep. Sci. Technol. 2015, 51, 269-277. [CrossRef]

15. Jasinski, S.M. Potash. In United States Geological Survey Minerals Yearbook; U.S. Geological Survey: Reston, VA, USA, 2017; pp. 128-129. 